\title{
Stomach function in relation to a scour syndrome in the piglet
}

\author{
By F. WHITE, G. WENHAM, G. A. M. SHARMAN, A. S. JONES, \\ E. A. S. RATTRAY AND I. MCDONALD \\ Rowett Research Institute, Bucksburn, Aberdeen
}

(Received 24 February-Accepted 2 fune 1969)

\begin{abstract}
I. Piglets were left to suckle their dam for about 2 days after birth to obtain colostrum and were then divided into four groups. One group was left with the sow, the second was given a standard liquid diet based on cow's milk, the third the standard diet with lactic acid added to give a $\mathrm{pH}$ of 4.8 , and the fourth the standard diet with the casein content increased by $50 \%$. Stomach samples were removed at intervals by stomach tube for $\mathrm{pH}$ measurements and bacteriological investigations. The tube was used immediately to give barium sulphate for radiographic examinations and was then withdrawn. Comparisons were made between treatments and between scouring and non-scouring piglets.

2. A diarrhoeic (scour) syndrome frequently developed; this was always preceded by diminishing gastric activity leading to gastric stasis. When spontaneous recovery occurred, there was a return of gastric function before recovery from scours and before the resumption of normal weight gain.

3. The incidence, duration and severity of the scour syndrome was less in piglets left on the sow; these differences could not be ascribed to the effect of colostrum. Piglets receiving the lactic acid milk diet had an average gastric $\mathrm{pH}$ of $\mathrm{I}$ unit less than the other piglets. Although the severity of scour and loss of clinical condition was less in the piglets given lactic acid milk the duration of reduced stomach motility was the same as in the other artificially fed piglets.

4. No obvious correlation was shown between the scour syndrome and the bacterial flora of the stomach or the intestines. The gastro-intestinal tracts of the piglets given lactic acid milk contained fewer bacteria than those of the piglets on the other diets.

5. Gross between-treatment differences at post-mortem were evident only in the stomach.

6. The spontaneous scour syndrome observed under the conditions of these experiments appeared not to be of bacterial origin but to be associated with a physiological malfunction of the stomach.
\end{abstract}

Piglets and calves that have died of scour are often found to have stomachs distended with clotted milk but empty small intestines (Sojka, 1965). Gross distension of the abomasum was the most consistent finding in a series of post-mortem (PM) examinations of early weaned calves dying of scour (F. White \& E. A. S. Rattray, unpublished observations).

In the first few hours after birth the baby pig acquires a stomach flora which gradually declines and almost disappears by the age of 3-4 weeks (F. White, G. A. M. Sharman \& E. A. S. Rattray, unpublished observations). Cranwell, Noakes \& Hill (I968) and Noakes, Cranwell \& $\mathrm{Hill}$ ( 1968 ) found that the onset of gastric $\mathrm{HCl}$ secretion in piglets may be delayed up to a month after birth, that the amount of lactic acid formed by bacterial fermentation in the stomach varies between piglets and that there are indications of an inverse relationship between the concentration of $\mathrm{HCl}$ and lactic acid in the stomach contents. They also suggested that in the achlorhydric pig the lactic acid produced by the gastric flora is sufficient to cause clot formation and to render the gastric $\mathrm{pH}$ suitable for enzymic clot formation. These observations suggested a direct 
relationship between $\mathrm{pH}$ and growth of bacteria in the stomach. A lack of lactic acidproducing organisms in the stomach of the achlorhydric piglet, with resultant high $\mathrm{pH}$ levels in the stomach, might be the condition required for the rapid growth of coliforms in the stomach. Such a condition could lead to the continuous passage of coliforms through the pylorus into the intestines leading, to the scour syndrome. It also seemed likely that if the $\mathrm{pH}$ of the gastric contents rose this could lead to impaired clot formation and reduced gastric digestion. Moreover, the growth of coliforms in the stomach could lead to diminished gastric acid secretion because of the release of endotoxin (Baume, Nicholls \& Baxter, 1967; Wyllie, Limbosch \& Nyhus, 1967).

Experiments were devised to examine in detail the phenomenon of gastric distension and its possible relationship to scours in piglets. In the expectation that the type of clot which developed in the stomach might be involved, cow's milk diets producing clots of different consistency were devised.

\section{EXPERIMENTAL}

\section{Experimental design}

For the first experiment ten litter-mate piglets were used in pairs after being left with their dam for $48 \mathrm{~h}$ after birth to ensure intake of colostrum. Pair I continued on the sow, pair 2 was given a standard rearing diet, pair 3 the standard diet plus lactic acid to give a pH of $4 \cdot 8$, pair 4 the standard diet with a $50 \%$ increase in casein concentration, and pair 5 the standard diet with a $50 \%$ decrease in casein concentration. In this preliminary experiment radiographic examination showed that on certain occasions stomach activity diminished and the passage of barium through the pylorus was reduced or ceased altogether because of stasis of the stomach. When these changes took place the piglet nearly always developed scour later. The low-casein diet was then discontinued as the results with it were similar to those for the other artificially fed groups. After the preliminary experiment four replicate experiments, each consisting of eight litter-mate piglets, were carried out. Blood samples were taken from the first eighteen piglets used when they were removed from the sow. Electrophoresis confirmed that they had all ingested an adequate amount of colostrum.

A sample of stomach contents was removed at $48 \mathrm{~h}$ intervals via a stomach tube, its $\mathrm{pH}$ was measured and the bacterial flora investigated. The stomach tube was removed after a barium sulphate suspension had been given.

Radiographs were taken of all the piglets $30 \mathrm{~min}$ and $60 \mathrm{~min}$ after the barium had been given, and with some piglets at varying intervals thereafter depending on the activity of the gastro-intestinal tract. The between-piglet comparison of gastric emptying rate was made from the $30 \mathrm{~min}$ and $60 \mathrm{~min}$ films. The animals were weighed daily and observed for clinical condition and scour. PM examinations were made on piglets which had died during the experiment, and all the survivors were slaughtered at 3 weeks or earlier, while scouring, for PM and bacteriological examination. 


\section{Animal procedures}

Animals. The piglets were from Large White sows by either Large White or Landrace boars and the sows were either first or second generation Minimal Disease pigs.

Housing. Open brooders in the Minimal Disease Piggery were used to house the piglets in pairs. Part of the floor area was slatted to allow dung and urine to pass through it, and in the other part a sheltered area with a heat lamp was provided to give a brooder temperature of $24^{\circ}$.

Feeding. A sterilized milk reservoir was filled each morning with the daily ration for each pair of pigs and was placed in a rack above the trough. The amount per pig was calculated according to age, being $200 \mathrm{ml}$ of a diet containing $20 \%$ dry matter on day $\mathrm{I}$ and increasing by $35 \mathrm{ml}$ daily to day $\mathrm{I} 3$. Thereafter the daily increase was more rapid so that on day 2I each pig received I4I I $\mathrm{ml}$. An automatic feeding device was set to deliver into the trough one-eighteenth of the ration every $75 \mathrm{~min}$ starting at I0.30 $\mathrm{h}$. In this way the last feed was given at $09.00 \mathrm{~h}$ next morning and the brooders were cleaned between then and $10.30 \mathrm{~h}$.

\section{Composition and preparation of diets}

Standard diet. Spray-dried cow's milk (Golden Glow; Unigate Ltd) was reconstituted at the rate of I $\mathrm{kg}$ milk powder to 3.51 . of water; $92 \mathrm{~g}$ of whole egg were added per 1 , and formalin was added to a final concentration of $0.1 \%$ to prevent bacterial action from causing clotting in the reservoir and tubes of the automatic feeder. In a preliminary trial formalin at this concentration was shown by histological examination not to cause any damage to the gut of piglets. The mixture was first homogenized in a Silverson homogenizer and was then passed twice through a highpressure homogenizer (Lawrence Scot Electro Motor Ltd) at $800 \mathrm{lb} / \mathrm{in}^{2}$.

Lactic acid diet. This was prepared from the standard diet by adding $5 \cdot 75 \mathrm{~N}$-lactic acid to give a $\mathrm{pH}$ of 4.8 ; casein remains in solution at this acidity.

Low-casein diet. This was prepared from the standard diet by adding $5.75 \mathrm{~N}-\mathrm{HCl}$ to precipitate the casein. The precipitated casein was removed and half of it re-dissolved in the whey by adjusting the $\mathrm{pH}$ to $6 \cdot 8-7.0$ with sodium carbonate.

High-casein diet. This was prepared from the standard diet by adding the surplus casein from the preparation of the low-casein diet to give a $50 \%$ increase in casein. The $\mathrm{pH}$ was adjusted to $6 \cdot 8-7^{\circ}$. The composition of the standard diet is shown in Table $\mathrm{I}$ and the composition of the mineral and vitamin supplements in Tables 2 and 3 . To the daily ration of each pair of piglets $2 \mathrm{ml}$ of the mineral supplement and $5 \mathrm{ml}$ of the vitamin supplement were added.

\section{Bacteriological procedure}

Collection of stomach samples. A sterile $35 \mathrm{~cm}$ stomach tube of $5 \mathrm{~mm}$ external diameter and $3 \mathrm{~mm}$ internal diameter, as used for human infants, was passed by mouth into the stomach. Between 2 and $3 \mathrm{ml}$ of contents were withdrawn into a sterile syringe. All air was expelled from the syringe, which was then immediately capped tightly. 
Samples were kept at $4^{\circ}$ until $\mathrm{pH}$ measurements and dilutions for bacteriological plating were made. A second syringe was applied to the stomach tube and barium sulphate was administered for radiography.

Table I. Percentage composition of the standard diet on a dry-matter basis

$\begin{array}{lr}\text { Crude protein } & 29 \cdot 2 \\ \text { Crude fat } & 27 \cdot 3 \\ \text { Lactose } & 38 \cdot 0 \\ \text { Ash } & 5 \cdot 5\end{array}$

Table 2. Mineral supplement

$\begin{array}{lcc}\text { Mineral } & \begin{array}{c}\text { Concentration } \\ (\mathrm{g} / \mathrm{l} .)\end{array} & \begin{array}{c}\text { Daily ration } \\ \text { (mg metal/pig) }\end{array} \\ \mathrm{FeSO}_{4} \cdot 7 \mathrm{H}_{2} \mathrm{O} & 79 \cdot 6 & 40 \\ \mathrm{CuSO}_{4} \cdot 5 \mathrm{H}_{2} \mathrm{O} & 3.12 & 2 \\ \mathrm{MnSO}_{4} \cdot 4 \mathrm{H}_{2} \mathrm{O} & 6 \cdot 52 & 4 \\ \mathrm{ZnSO}_{4} \cdot 7 \mathrm{H}_{2} \mathrm{O} & 17 \cdot 66 & 10\end{array}$

Table 3. Vitamin supplement

$\quad$ Vitamin
Vitamin $K$
Vitamin $D_{3}$
Vitamin $B_{12}$
Nicotinic acid
Pantothenic acid

$\begin{array}{cc}\text { Concentration } / 1 . \mathrm{H}_{2} \mathrm{O} & \text { Amount/pig day } \\ 2 \mathrm{ml} \text { of } 0.5 \mathrm{~g} / 100 \mathrm{ml} \mathrm{EtOH} & \text { 10 } \mu \mathrm{g} \\ \mathrm{ml} \mathrm{of} 0.5 \mathrm{ml} / 100 \mathrm{ml} \mathrm{EtOH} & \text { 100 i.u. } \\ 4 \mathrm{ml}(250 \mu \mathrm{g} / \mathrm{ml}) & 1.0 \mu \mathrm{g} \\ 2.5 \mathrm{~g} & 2.5 \mathrm{mg} \\ 0.5 \mathrm{~g} & 0.5 \mathrm{mg}\end{array}$

Collection of samples from stomach and intestine at end of experiment. Samples of stomach contents were collected by stomach tube immediately before killing. The pigs were killed by intravenous injection of pentobarbitone. Immediately after opening the peritoneal cavity the small intestine was severed mid-way between the pylorus and the ileo-caecal valve, and the contents from each portion were squeezed with the fingers into sterile containers. Some samples were also taken in a similar way from the colon.

Bacteriological methods. One-tenth dilutions of the samples in broth saline were homogenized for $3 \mathrm{~min}$ and further one-tenth dilutions up to $10^{-6}$ were made. Samples and dilutions were kept throughout in an ice-bath. Bacterial counts were obtained by plating sample dilutions on to three different media in plates which had been divided with a pencil marker into five segments. A platinum wire loop of 22 SWG adjusted in size to deliver $0.01 \mathrm{ml}$ was used throughout, and five counts were made on each segmented plate. At least three dilutions from each sample were plated out. Usually six or more serial dilutions were plated to ensure that on some plates colonies were adequately spaced for counting. The bacterial count $/ \mathrm{ml}$ was calculated by the method of Finney (1952).

Media. Oxoid McConkey Agar No. 2 was incubated aerobically for $24 \mathrm{~h}$. Oxoid Blood Agar Base No. 2, plus 5\% whole sheep blood in glucose-citrate solution as anticoagulant, was incubated anaerobically for $24 \mathrm{~h}$. Rogosa, S.L. Medium (Rogosa, Mitchell \& Wiseman, I95I) was incubated anaerobically for $48 \mathrm{~h}$. Anaerobiosis was 
achieved with $95 \% \mathrm{H}_{2}, 5 \% \mathrm{CO}_{2}$ in a McIntosh and Fildes jar. The incubation temperature was $37^{\circ}$.

\section{Measurement of $p H$}

The sealed and cooled stomach samples were transferred to sterile capped beakers and $\mathrm{pH}$ measurements were made with a Radiometer meter. Preliminary work showed that repeat $\mathrm{pH}$ measurements taken $\mathrm{I} h$ after the first reading with samples left at room temperature showed upward drifts of $0-0.2$ of a $\mathrm{pH}$ unit. Measurements were always made less than $\mathrm{I} h$ after collection.

\section{Radiographic procedure}

A single phase self-rectified portable Unit (General Radiological) was used. Radiographs were taken at $50-55 \mathrm{kV}$, I $5 \mathrm{~mA}$, with an exposure of $0.25 \mathrm{sec}$. Focus to film distance (FFD) was $90 \mathrm{~cm}$. The film used was Ilford Red Seal with standard calcium tungstate intensifying screens. Radiographic examination was carried out in the brooder room.

Barium sulphate (Micropaque-Damancy) diluted with an equal volume of water was administered to each pig by stomach tube. The volume chosen, $5 \mathrm{ml}$ Micropaque, was considered to be the optimum for outlining the stomach and intestines in piglets of the age used here without distending or overloading any part.

The piglet was held by the fore-limbs and hind-limbs against a vertical cassette holder, which was positioned on the left side of the piglet. Using a horizontal X-ray beam, the central ray was directed to the centre of the trunk of the piglet on the side nearest the tube. The horizontal lateral view was chosen in order to show fluid levels within the gastro-intestinal tract.

\section{RESULTS}

\section{Bacteriological observations}

A total coliform count was obtained from the McConkey medium plates and a total Lactobacilli count from the Rogosa plates. From the blood agar plates a total count and a haemolytic coliform count were obtained.

Mean values for each treatment are given in Table 4. Although observations of the bacteriology and $\mathrm{pH}$ of gastric samples were made on all the piglets only results for those piglets for which there were six or more samples out of a possible ten, i.e. every $48 \mathrm{~h}$ over the $2 \mathrm{I}$ days of the experiment, have been included. Stomach contents from the piglets given lactic acid had lower $\mathrm{pH}$ values and generally much lower counts than either the sow-reared piglets or the other two artificially reared groups. The differences in counts were not related to the observed differences in incidence of scouring from treatment to treatment, with the possible exception of those of haemolytic coliforms, which were lower for the sow-reared and the lactic acid groups than for the standard and high-casein groups.

When the values for each piglet were plotted against time it was noted that those for the lactic acid group were much more variable from day to day than those for the other groups. The only clear trends with time were in $\mathrm{pH}$, which tended to rise over 
the first few days in all the treatment groups. An attempt was made to compare $\mathrm{pH}$ values and bacterial counts on the same piglets between occasions when they were or were not scouring. The results are given in Table 5 and show no significant differences between the mean values under the two conditions.

Table 4. Observations on the bacteriology and $p H$ of gastric samples, and on the clinical condition of piglets reared on the sow or receiving three artificial milk diets

(Mean values and standard errors are given for each treatment)

No. of piglets

$\log$ (lactobacilli count)

$\log$ (coliform count)

$\log$ (haem-coli count)

$\log$ (blood agar count)

$\mathrm{pH}$

Weight gain ( $\mathrm{kg} /$ day)

No. of piglets scouring

Mean days scour/piglet

Days scouring as \% of total days

Gastric malfunction, days observed as $\%$ of total days

$\begin{array}{ccc}\begin{array}{c}\text { Normal } \\ \text { diet }\end{array} & \begin{array}{c}\text { Lactic acid } \\ \text { diet }\end{array} & \begin{array}{c}\text { High-casein } \\ \text { diet }\end{array} \\ 7 & 6 & 6 \\ 8.01 & 7.20 & 7.74 \\ \pm 0.12 & \pm 0.51 & \pm 0.11 \\ 6.88 & 5.05 & 6.67 \\ \pm 0.25 & \pm 0.56 & \pm 0.27 \\ 4.95 & 4.06 & 5.10 \\ \pm 0.28 & \pm 0.46 & \pm 0.25 \\ 8.11 & 7.71 & 8.05 \\ \pm 0.23 & \pm 0.28 & \pm 0.16 \\ 5.10 & 4.21 & 5.23 \\ \pm 0.14 & \pm 0.17 & \pm 0.16 \\ 0.088 & 0.096 & 0.050 \\ \pm 0.034 & \pm 0.018 & \pm 0.032 \\ 7 & 3 & 6 \\ 6.0 & 1.0 & 3.5 \\ 41 & 6 & 32 \\ 55 & 56 & 45\end{array}$

Table 5. Log of bacterial counts and $p H$ values of gastric samples taken from piglets on the normal diet or on the high-casein diet, on days when piglets were or were not scouring

(Mean values and standard errors are given for each treatment)

\begin{tabular}{lcccc} 
& \multicolumn{2}{c}{ Normal diet } & \multicolumn{2}{c}{ High-casein diet } \\
& Not scouring & Scouring & Not scouring & Scouring \\
$\log$ (lactobacilli count) & 7.87 & 8.27 & 7.49 & 8.00 \\
$\log$ (coliform count) & \pm 0.16 & \pm 0.22 & \pm 0.30 & \pm 0.29 \\
$\log$ (haem-coli count) & 6.93 & 6.53 & 6.65 & 6.86 \\
$\log$ (blood agar count) & \pm 0.29 & \pm 0.29 & \pm 0.26 & \pm 0.37 \\
pH & 4.93 & 4.80 & 4.88 & 5.53 \\
& \pm 0.30 & \pm 0.35 & \pm 0.22 & \pm .42 \\
& \pm 0.24 & \pm 0.34 & \pm 0.16 & \pm 0.23 \\
& 5.09 & 4.95 & 5.18 & 5.40
\end{tabular}

\section{Radiological findings}

All the piglets were given barium sulphate and the time of administration was noted so that they were all radiographed after the same time intervals. The pattern observed in the healthy pigs was taken to be normal; departures from it were considered to be abnormal.

In normal piglets a considerable amount of barium had passed through into the small intestine after only 5 min while some barium was still retained in the stomach. 
The stomach was small and active with the barium well mixed with the stomach contents (P1. $\mathrm{r} a$ ). After a further $25 \mathrm{~min}$ the stomach contained only traces of barium and the small intestine was outlined to the ileum.

After approximately $2.5 \mathrm{~h}$ the barium was contained wholly within the ileum, and after a further hour the caecum and proximal spiral colon were outlined. From then on there was a slow passage through the colon, barium first reaching the rectum in approximately $12 \mathrm{~h}$. Some barium could still be seen in formed faeces in the distal colon and rectum of the normal piglets $48 \mathrm{~h}$ after barium was given ( $\mathrm{Pl} . \mathrm{I} b$ ).

From a study of the radiographs of the normal healthy piglets the following points emerged:

(I) The stomach was small and very active.

(2) Barium sulphate had passed out of the stomach completely after 30-45 min.

(3) The filling of the small intestine was good and even.

(4) The barium could still be seen in the faeces after $48 \mathrm{~h}$, showing that there was a slow rate of passage through the colon.

It seemed quite normal for the stomachs of piglets to contain a quantity of clotted material, but the stomach maintained normal proportions by digesting away this material in the pyloric antrum as quickly as it was being built up in the stomach (Pl. Ic).

The first change from the normal was observed in piglets which had been removed from the sow and had not yet learned to take food from a trough. The barium was retained in the caecum and spiral colon and sometimes took longer than $42 \mathrm{~h}$ before becoming evident in the rectum radiographically. Once the piglets started to eat the rate of passage returned to normal.

The first serious deviation from normal, which occurred in every piglet subsequently affected by the scour syndrome under investigation, was a reduction in the gastric emptying rate. The stomach took longer to empty at first, often taking from I to $\mathrm{I}^{\prime} 5 \mathrm{~h}$ to reach the stage normally seen after $30 \mathrm{~min}$. This delay in gastric emptying became progressively longer. After $30 \mathrm{~min}$ and often after $90 \mathrm{~min}$ the barium was still contained in the stomach with no trace in the small intestine. What little barium did eventually pass through was seen on the radiographs as widely spaced flocculated pockets, compared with the almost continuous column seen in normal piglets.

The stomach at this initial stage (P1. 2a) was still quite small, though lacking in muscular activity. This lack of activity was well demonstrated with the piglets fed on a diet which did not form a solid clot. In these liquid-filled stomachs there could be seen two fluid levels, a lower level of barium and a higher level of fluid food material outlined by the gas shadow in the upper body, fundus and diverticulum (P1. $2 b$ ). As the piglets continued to take food, the stomach became more and more distended, sometimes taking up about half of the abdominal cavity (Pl. $2 c$ ). The muscular wall of the stomach appeared to be completely lacking in tone with no visible signs of activity; it hung flaccid, like a balloon partly filled with water, with the base flattened where it lay in contact with the ventral abdominal wall (Pl. $3 a$ ).

While the activity was diminishing in the stomach, the opposite was taking place in the intestines. Piglets given a barium meal did not show any residual barium distal 
to the pylorus $24 \mathrm{~h}$ later, a process which normally took upwards of $48 \mathrm{~h}$. Pl. $3 b$ shows a piglet exhibiting a flaccid stomach containing a barium level, flocculated barium in the small intestine, and a large intestine which was filled from caecum to rectum with barium administered $12 \mathrm{~h}$ previously. The piglet started to scour and cleared all the barium except for some in the caecum and some still in the stomach in a period of 3.25 h (Pl. 3c).

The radiological sequence of events associated with this scour syndrome was as follows:

(a) Gastric hypomotility leading to a greatly reduced rate of passage from stomach to duodenum. Barium was occasionally retained in the stomachs of affected piglets for up to $37 \mathrm{~h}$ after its administration. The stomach became flaccid and distended as the piglet continued to eat, with the appearance of either a double fluid level when barium was given to piglets on diets less likely to clot $(\mathrm{PI} .2 b)$, or a large barium mottled clot filling the whole of the stomach, or with the convexity of the clot showing against the gas in the fundic region in the piglets fed on diets most likely to form a clot (Pl. 4a).

(b) The rate at which barium passed through the small and large intestine was increased. It would be difficult to state with certainty that stomach contractions had ceased completely, or that there was increased peristaltic activity in the intestines; no signs of activity however could be seen on the radiographs of the apparently flaccid, distended stomachs. It is most unlikely that the radiographic exposures were made with the stomachs in the relaxed phase every time.

(c) The sequel was either spontaneous recovery or death, depending on whether the duration of scouring was a few hours or a few days. During recovery the stomach showed signs of activity, there was a more rapid passage of barium into the small intestine, and more normal faeces were seen in the rectum. The clotted contents of the stomach broke up first in the pyloric antrum through increased muscular activity in the stomach wall, and the stomach returned to more normal dimensions. There were often periods of partial recovery.

\section{Table 6. Incidence of scour and gastric malfunction in piglets left to suckle their dam, or receiving artificial milk diets}

\begin{tabular}{|c|c|c|c|c|c|}
\hline & Sow & $\begin{array}{c}\text { Normal } \\
\text { diet }\end{array}$ & $\begin{array}{c}\text { Lactic acid } \\
\text { diet }\end{array}$ & $\begin{array}{c}\text { High-casein } \\
\text { diet }\end{array}$ & $\begin{array}{c}\text { Low-casein } \\
\text { diet }\end{array}$ \\
\hline No. of piglets & IO & I0 & IO & 10 & 2 \\
\hline Scoured & 6 & 10 & $3 *$ & IO & 2 \\
\hline Deaths & 0 & I & 0 & 2 & 0 \\
\hline Gastric stasis & 6 & IO & I0 & 10 & 2 \\
\hline
\end{tabular}

* The seven piglets which did not scour on the lactic acid diet had loose faeces.

The piglets that were affected by scour while sucking the sow showed the same sequence of events as those reared artificially. Whatever means of feeding were used, the same physiological effects were seen on all the piglets that were either scouring or going to scour.

It should be noted that although the lactic acid group had a low incidence of scouring (Table 4) the incidence of stomach malfunction was as high as for the other two 
artificially reared groups, and the mean rate of live-weight gain was correspondingly low.

P1. $4^{b}$ shows a pig fed lactic acid with an enlarged flaccid stomach with stasis, and no barium present in the small intestine $30 \mathrm{~min}$ after its administration. Barium from the previous day's administration was present in formed faecal pellets in the colon, showing that gastric stasis preceded the scour which followed 2 days later.

\section{Post-mortem observations}

It was not possible to examine immediately the carcasses of piglets that died. However, by ignoring early autolytic change it could be seen that the findings resembled those in the scouring piglets that were killed. In these the stomachs were large and the secretory mucosa was hyperaemic. The small and large intestines were either full of watery fluid or were empty. In some piglets sunken eyes and dryness of the loose connective tissues were indications of dehydration.

Gross between-treatment differences were evident only in the stomachs. Scouring piglets which had been consuming the high-casein diets each had a large hard laminated clot distending the stomachs. These are shown in Pl. 4, $c$ and $d$. The naturally suckled piglets had a softer clot which was granulated in the centre and laminated at the periphery, while the piglets fed lactic acid had stomachs filled with semi-solid gelatinous curd. In the non-scouring piglets the stomachs were small and contained small clots or curds which varied from hard to soft in the order of diet, high-casein, standard, naturally suckled, lactic acid milk. The size of the stomach rugae also varied in the same order according to diet; they were least prominent in piglets given the highcasein diet and most prominent in those given lactic acid milk.

\section{DISCUSSION}

Scour in young animals is generally assumed to be of bacterial aetiology. Although it is not inferred that scour of a bacterial aetiology does not exist, this investigation was undertaken to examine other factors, with particular emphasis on a commonly observed sign seen at post-mortem, namely a distended stomach.

The symptoms of hypomotility and hypotonicity with eventual stasis and food retention, leading to distension of the stomach, preceded all the clinical signs of this spontaneously occurring scour syndrome, and the return of gastric function preceded the recovery from clinical scour.

A total of fifty piglets has now been examined, and in none of them has scour been observed without being preceded by gastric stasis, although gastric stasis of short duration was observed to occur without scour.

Gastric stasis was found to be unrelated to the nature of the milk clot that developed in the stomach; it occurred on the high-casein and the standard cow's milk diets which formed hard casein clots, on the naturally sucked sow's milk which formed a soft clot, and also on the lactic acid milk which formed an even softer clot.

The bacterial counts on the stomach samples showed no significant tendency to increase or decrease according to whether the piglet was or was not scouring at the 
time of sampling. Again, bacterial counts on samples from the anterior and posterior small intestines of piglets killed at the end of the experiment showed no significant variations between scouring and non-scouring animals. Both findings suggest that if the syndrome was of bacterial origin it was not caused by the groups of bacteria that were counted during this investigation.

It is not possible to draw any very definite conclusions from the differences in mean bacterial counts from one treatment group to another. The blood agar, lactobacillus and coliform counts were as high for the sow-reared piglets as for the other groups or higher, and since there was less scouring in the sow-reared piglets these counts were evidently unrelated to the incidence of scour. The counts of haemolytic coliforms for the sow-reared group, although very variable, were lower than for the other groups, but they were almost as low on average for the lactic acid group, which was as much subject to stasis, although not to scour, as the other artificially reared groups. It might be suggested therefore that high counts of haemolytic coliforms can lead to scouring under conditions of stomach malfunction but that the high counts do not seem to be responsible for the malfunction itself. By keeping the haemolytic coliform count at a lower level, the lactic acid diet may give the piglets a better chance to recover from stomach malfunction without scouring.

The growth performance of all the piglets with gastric stasis was poor whether or not they developed scour (Table 4 ). Weight gain either ceased or was reduced to a very low level immediately stomach stasis was observed, and eventually weight loss was observed. Unthriftiness might therefore be considered to result from the failure of nutrients to pass through the pylorus because of the stomach malfunction, leading to starvation, debility and eventually to a moribund condition if the stomach malfunction persisted long enough. Under such conditions, invasion of the body by the normal flora of the gut could occur, hastening death. Some coliform strains could invade earlier than others and this would account for certain coliform serotypes and not others being associated with a more severe clinical condition and higher mortalities in scour. It is suggested that the bacterial flora of piglets moribund or dead as the result of scour would not be significantly different either in numbers or composition from that of piglets moribund or dead as the result of any other non-infective cause.

Treatment of the diet with lactic acid effected some control over the bacterial population of the gastro-intestinal tract and also over the incidence of scour. However, since it did not prevent stasis of the stomach it can only be regarded as a method of controlling a secondary manifestation of scour, possibly by delaying invasion of the body by the normal flora of the gut.

There did not appear to be a true pyloric obstruction since some of the liquid fraction of the diet did get through into the small intestine.

It is surprising that piglets having a grossly distended stomach should retain any appetite at all, but they did although some of them vomited soon after feeding. Possibly the flaccid condition of the stomach prevented stimulation of stretch receptors in series with the musculature, which inhibit appetite.

In the past too little attention has been paid to the physiology of the scour syndrome, and investigations of gastric physiology should prove particularly rewarding. 
Our thanks are due to Mr J. Wood for supply of Minimal Disease piglets, Mr I. Phillips and Miss S. Ball for care of the piglets, Mr D. Davidson for the preparation of bacteriological media, Dr E. I. McDougall for electrophoresis of piglet serum, Mr I. Robb and Mr R. Middleton for photographs and Miss J. Wilson and Miss J. Murison for technical assistance.

\section{REFERENCES}

Baume, P. E., Nicholls, A. \& Baxter, C. H. (1967). Nature, Lond. 215, 59.

Cranwell, P. D., Noakes, D. E. \& Hill, K. J. (1968). Proc. Nutr. Soc. 27, 26 A.

Finney, D. J. (1952). Statistical Method in Biological Assay p. 574. London: Griffith \& 6

Noakes, D. E., Cranwell, P. D. \& Hill, K. J. (I 968). Proc, Nutr. Soc. 27, 2 A.

Rogosa, M., Mitchell, J. A. \& Wiseman, R. F. (1951). F. Dent. Res. 30, 682.

Sojka, W. J. (1965). Rev. Ser. Commonw. Bur. Anim. Hlth no. 7.

Wyllie, J. H., Limbosch, J. M. \& Nyhus, L. M. (1967). Nature, Lond. 215, 879.

\section{EXPLANATION OF PLATES}

\section{Plate I}

(a) Radiograph of a normal piglet taken 5 min after barium was given. Some barium is in the stomach, and some has passed into the small intestine. (Reared on the sow.)

(b) Radiograph of a normal piglet taken 30 min after barium administration. It shows that all the barium has passed out of the stomach into the small intestine. There is some residual barium in the colon and rectum from barium given $48 \mathrm{~h}$ previously. (Reared on the sow.)

(c) A normal piglet $\mathrm{X}$-rayed $30 \mathrm{~min}$ after barium was given. It shows that although there was solid material in the stomach the barium passed freely into the small intestine. (Reared on the standard diet.)

\section{Plate 2}

(a) The first signs of gastric stasis in a piglet. This film was taken $30 \mathrm{~min}$ after barium was given. Though the stomach was still quite small, the barium fluid level indicated a lack of gastric activity with no passage of barium into the small intestine. There was some residual barium in the caecum and spiral colonfrom a previous barium meal. (Reared on the lactic-acid diet.)

(b) Gastric stasis. This film was taken $30 \mathrm{~min}$ after barium was given. Note the double fluid level in the stomach and the flaccid outline of the stomach wall. There is a small amount of barium in the proximal small intestine which has also settled into fluid levels. (Scouring.) (Reared on the low-casein diet.)

(c) A large barium mottled clot is filling a distended stomach. Some barium has reached the small intestine, probably due to physical distension of the pylorus by the clot. (Scouring.) (Reared on standard diet.)

Plate 3

(a) A large flaccid liquid-filled stomach in a piglet. The barium has settled to the greater curvature of the stomach which is flattened against the abdominal wall. No barium has passed into the small intestine. (Scouring.) (Reared on lactic-acid diet.)

(b) Residual barium in the caecum and spiral colon, and in formed faeces in the descending colon and rectum from a barium meal given $\mathrm{i} 2 \mathrm{~h}$ previously. The barium showing as a fluid level in the stomach and in flocculated pockets in the small intestine is barium given $1 \cdot 5 \mathrm{~h}$ previously. (Not scouring.) (Reared on lactic-acid diet.)

(c) The same piglet as in (b). This film was taken $3.25 \mathrm{~h}$ later as the piglet started to scour. All the barium has been voided except for traces in the spiral colon, some in the caecum and that still in the stomach. 


\section{Plate 4}

(a) A radiograph taken $30 \mathrm{~min}$ after administration of barium to a scouring piglet. It shows a large barium mottled clot partly filling a flaccid stomach. There has been no passage of barium into the small intestine. Though this piglet had been given barium $24 \mathrm{~h}$ previously, there was no residue in the colon or rectum. (Reared on the high-casein diet.)

(b) A flaccid stomach showing two fluid levels $30 \mathrm{~min}$ after a barium meal. There has been no small intestinal filling. The residual barium in firm, formed faeces in the colon and rectum from a barium meal given $24 \mathrm{~h}$ previously clearly indicates that gastric stasis preceded the scouring that followed some hours later. (Reared on the lactic-acid diet.)

(c) The opened enlarged stomach in situ of a scouring piglet showing milk clot. (Reared on standard diet.)

(d) As for $(c)$ except that the clot is cut in half showing a greyish area of decomposition in the centre. 
British Yournal of Nutrition, Vol. 23, No. 4

Plate I
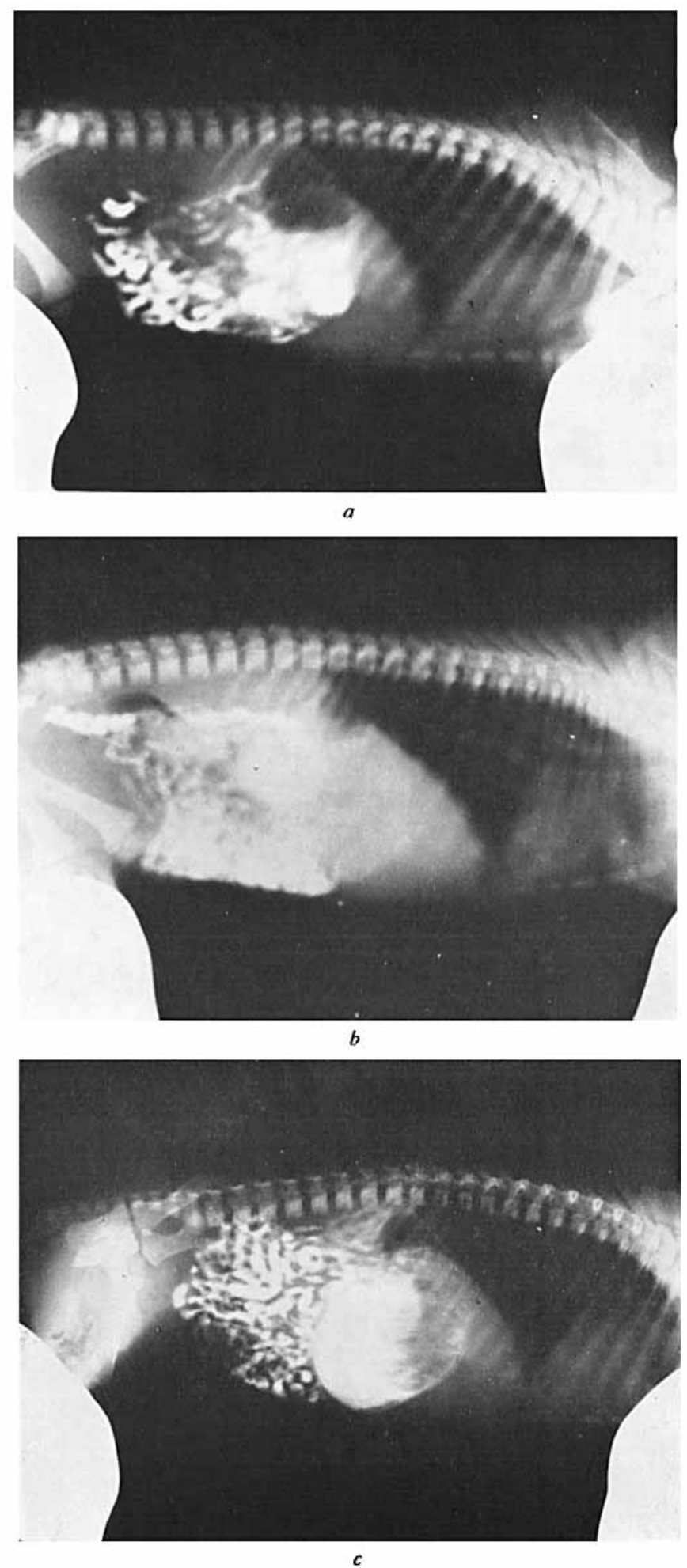
British fournal of Nutrition, Vol. 23, No. 4

Plate 2
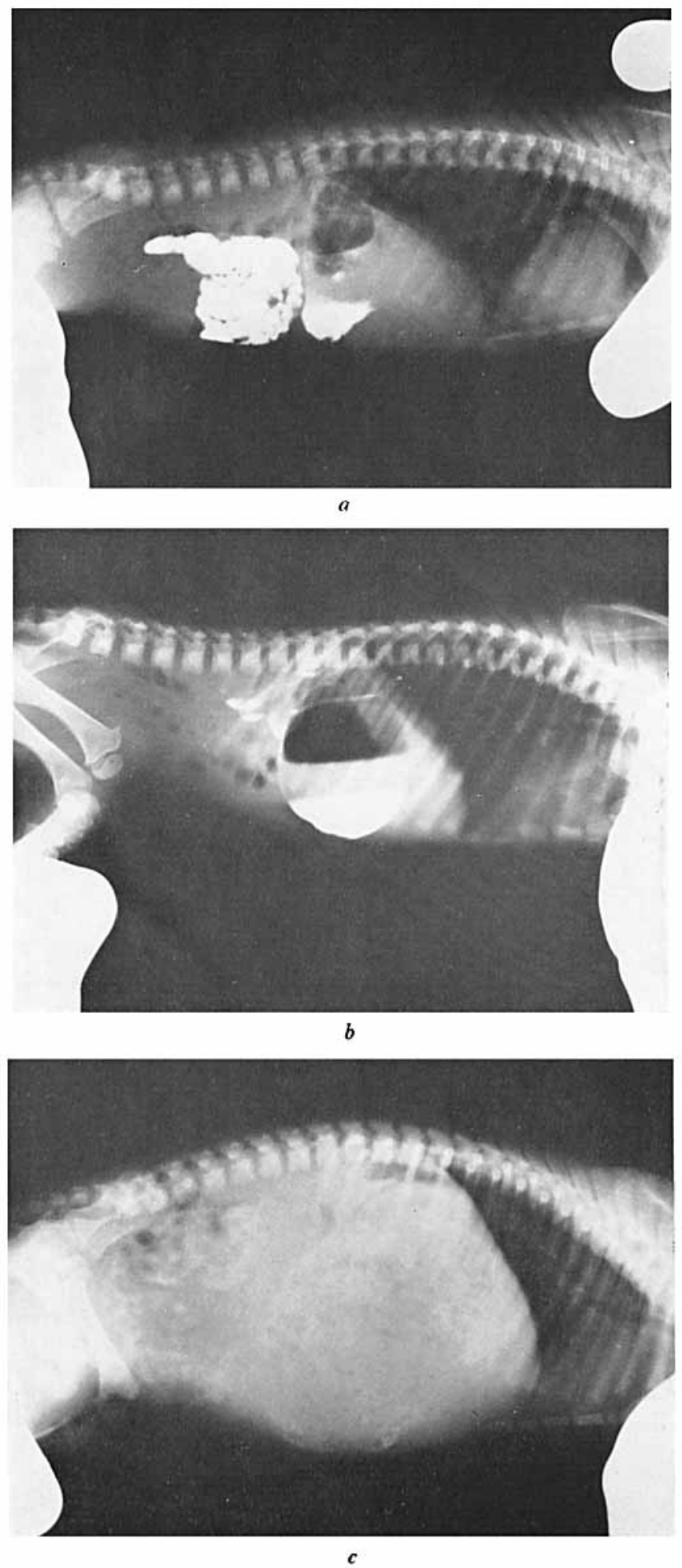

F. WHITE AND OTHERS 
British Yournal of Nutrition, Vol. 23, No. 4

Plate 3
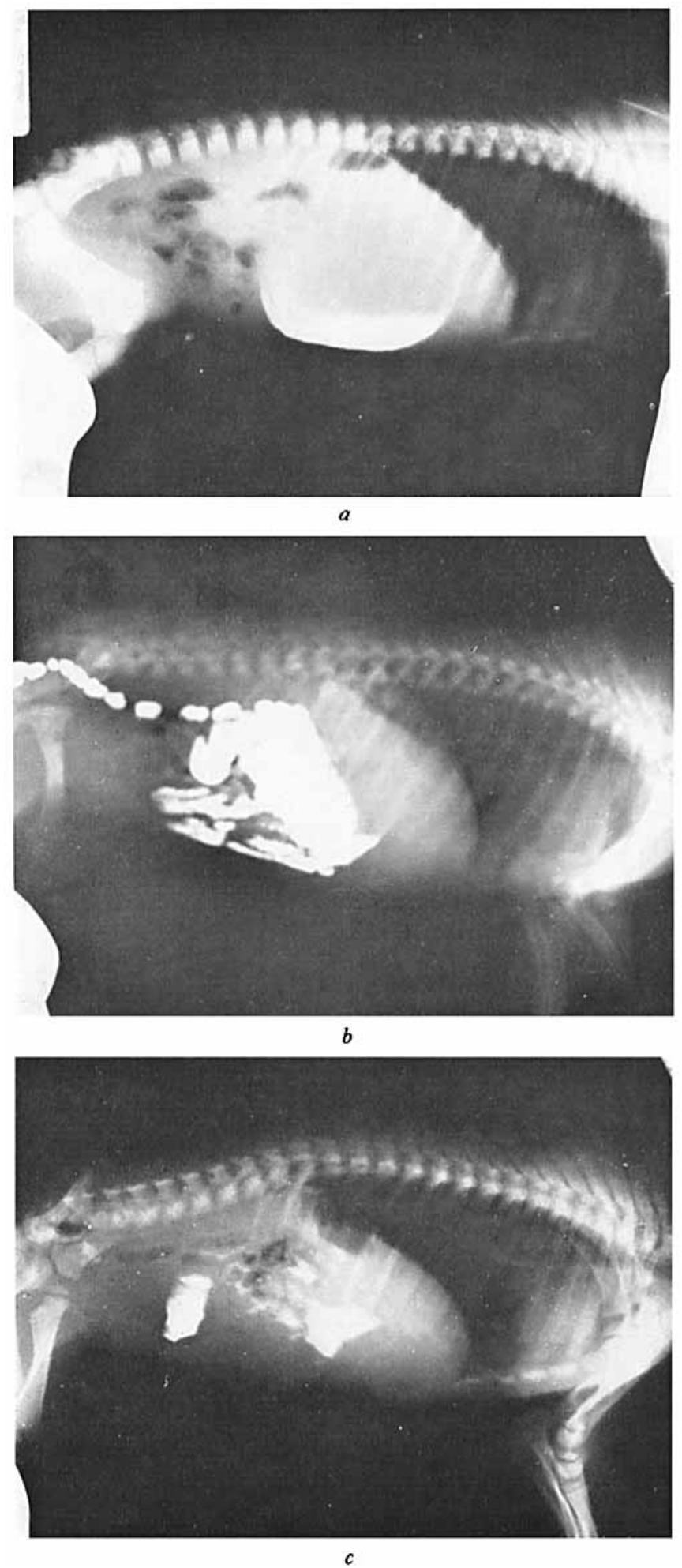

F. WHITE AND OTHERS 
British Fournal of Nutrition, Vol. 23, No. 4

Plate 4
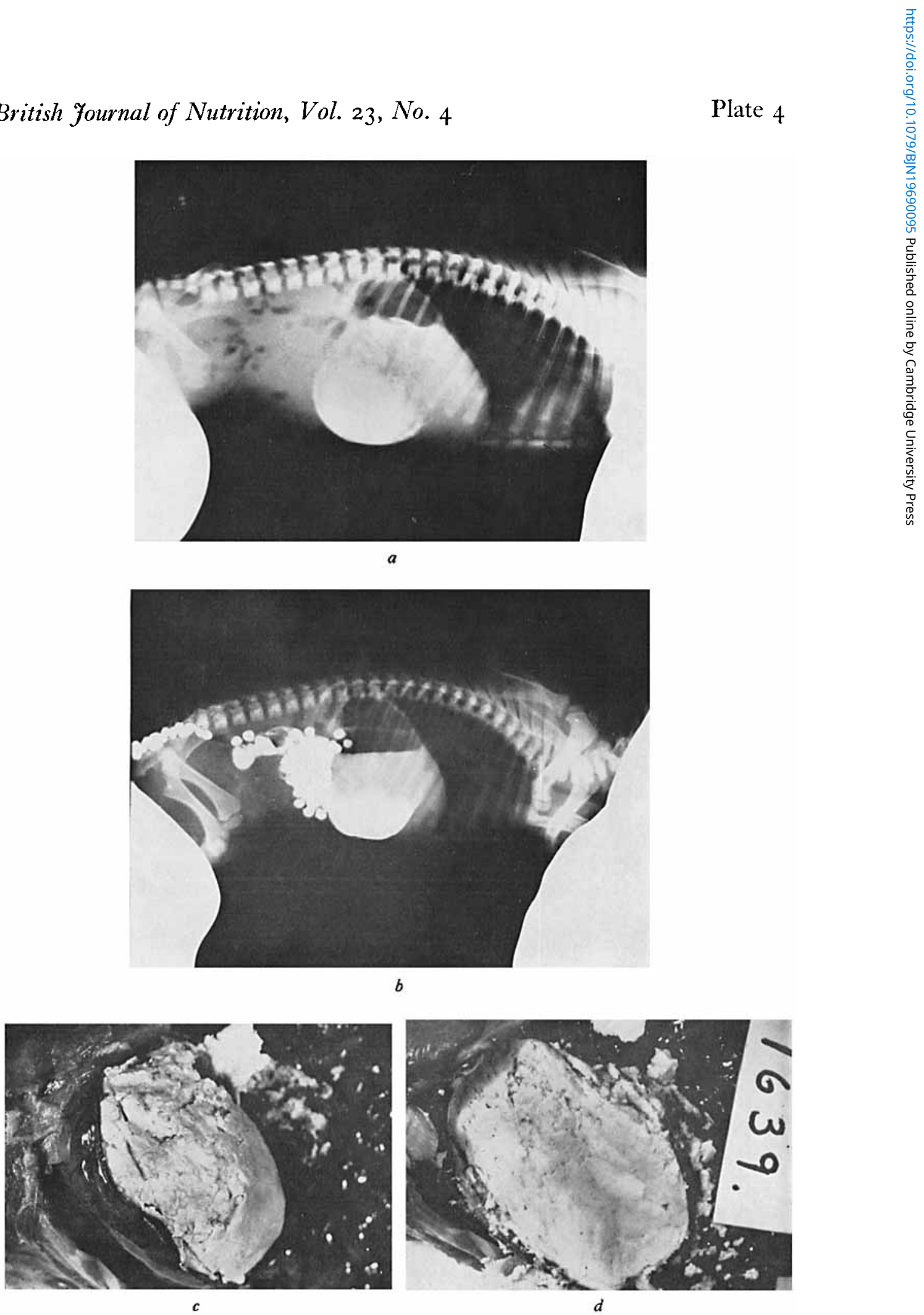

F. WHITE AND OTHERS 